\title{
Exploring Alternative Strategies for Democratic Consolidation in Nigeria: The Role of Political Parties
}

\author{
Imoh, Ita-Imoh \\ Lecturer Akwa-Ibom State Polytechnic, Nigeria \\ Gbenegbara, Sampson.N
}

Lecturer Rivers State Polytechnic, Bori-Ogoni Nigeria

Doi:10.5901/mjss.2014.v5n23p1729

\begin{abstract}
Democracy in Nigeria appears to be very unstable. Nigeria has no visible traces of substantial democratic credentials, yet there is so much of this democratic noise in the country. This made the. The practice of democracy is without code of conduct, hence defections of political gladiators from one parties to another is the order of the day. These practice potent danger for the nations democracy the basis for this position is that political parties have greater role to play in the nation's democratic practice.
\end{abstract}

\section{Introduction}

The collapse of the Soviet Union and the subsequent relaxation of the cold ward in the 1990s led to an unprecedented increase in the number of countries which willingly opted for the democratic option.

To this end, many countries now lay claim to practicing one form of democracy or the other. Yet the defining features that characterized a good number of these countries are political tension, lack of respect for the fundamental rights of man, press censorship and absence of the rule of law. Nigeria falls under the category of countries that incur great cost and pains to put democracy in place and so pretend to be democratic while in actual fact the bulk of those entrusted to sow the seeds of democracy and to distribute its dividends to the people are all anti-democracy after all.

This chapter therefore examines the role expected of political parties in the consolidation of democracy in Nigeria. The approach used is qualitative as data was gathered primarily from secondary sources and analyzed via content and historical analysis. The author posits that there is a direct significant relationship between the character and conduct of a country's political parties and the degree of democratic consolidation in that country.

The global acceptance of liberal democracy as a vehicle for the attainment of peaceful co-existence in a multifaceted society such as Nigeria gives credence to the quest for the consolidation of democracy in the country. Liberal democracy is seen as an instrument for the promotion of economic development, liberty, human rights restoration, rule of law and freedom of healthy competition among various interests in a country. A country whose democracy is still in the incubator and one that is just staggering out of long years of military dictatorship such as Nigeria needs holistic strategies to serve as lubricants for the consolidation of the tenets of democracy in the country. Political parties are seen as the machinery for the coordination and organization of these strategies.

Our primary concern in this chapter therefore is the determination of the extend to which political parties in Nigeria have contributed and are still contributing to the sustenance of our fragile democracy. To achieve, this, answers need to be provided to questions such as: of what relevance are political parties in the preservation of democratic norms and principles necessary for the consolidation of democracy in Nigeria? Does the structure and formation of political parties in Nigeria effective enough to bring about stable democracy in the country? Are Nigerian political parties institutionalized? Do Nigerian parties pursue meaningful ideologies that have direct positive bearing on the lives of the citizens? Are opposition parties alive to their responsibilities in the country? Answers to these questions will help us determine the actual role of political parties in the sustenance of democracy in Nigeria.

Democracy exists where political leaders are selected by competitive elections in which the greater parts of the population have the opportunity to participate. According to Sarabjit, K. (2002), the condition of the parties in a political system is the best possible evidence of the nature of any democratic regime in its original formulation. In other words, the health and standard of the existing political parties in a country determine the credibility and sustainability of the 
democratic regime in that country.

\section{Conceptual Clarification}

It is difficult to give precise definitions to concepts and terms in the social science discipline. This is so because different persons give different definitions to different concepts and terms depending on their individual perception of those concepts used in this chapter are generally defined and particularly operationalized to capture the meaning which the researcher seeks to impose on them. Such concepts include:

1. Democratic Consolidation - Democratic Consolidation refers to the sustenance of the practice of democracy and the preservation of those institutions through which the ideals of democracy are formulated, expressed and realized. Democratic consolidation does not necessarily means the creation of National Assembly, States House of Assembly, the operation of a Constitution and the existence of the Judiciary. Democracy is consolidated when the principle of separation of powers among the various organs of government is fully respected, where there is press freedom and freedom of expression, where the constitution is supreme and the rule of law fully respected and where the fundamental rights of man are not only theoretically entrenched in the constitution but practically promoted and guaranteed.

2. Political Party - Political party is an organized group with a common political philosophy which seeks to win and retain public office for itself, and its leaders, the elites. The organization of political parties is the direct outcome of the introduction of representative government. According to Ranny and Kenall (1956:1), political parties are autonomous organized groups that make nominations and contest elections with the hope of controlling personnel and policies of government.

3. Political Ideology - Political ideology is a very crucial element in a country's power configuration. Unlike other tangible elements of national power such as geography and population, political ideology is difficult to give a precise definition. For the purpose of our discussion in this chapter, political ideology is defined as a generic term that covers political ideals, ideas, attitudes, sentiments and slogans with varying degrees of commitment to action for the realization of the ideals or ideas.

4. Political Philosophy - Political philosophy is an abstract and normative aspect of political science that deals with the principles of political organization and party formation and the evaluation of the changes needed in the existing political framework. Its emphasis is more or less on the future course of action.

\section{Theoretical Framework}

Our discussion in this chapter is best fixed into the elite theoretical framework because political parties and governance are dominated and decided by the elites. The elite theory is a theory of the state which seeks to describe and explain the power relationships among various interests in a modern society. The theory posits that a small minority consisting of members of the economically dominant elite holds the most important power in a society and that this power is independent of a state's democratic electoral process.

The classical exponents of the elite theory include Vilfredo Pareto and Gaetano Mosca (Italians) and Robert Michaels (a Swiss). To them, every society is ruled by a small (minority) group of people who possess the attributes that made it possible for them to ascend to the top. The elite therefore consist of those successful persons who rise to the top in every occupation and stratum of society. In his work, "The Ruling Class", Gaetano Mosca (1930), rightly observed that in all societies, two classes of people exist: a class that rules and a class that is ruled.

Political parties in Nigeria are controlled by very few individuals in the party (the class that rules) who have besieged the available posts and positions in the upper hierarchy of the parties. These few influential, wealthy and powerful individuals who are in the minority make all the decisions while others follow. They are the elites. The political parties in Nigeria are dominated by the dictates of these elites while the masses, the class that is ruled, follow without choice. Electoral protocols could be broken just to satisfy the interest of these elites. It was evident that in the 2003 general elections in Nigeria, some governorship aspirants did not campaign but at last they won, not because of their popularity but just because the elites wanted them there. Former governor of Anambra State, Senator Chris Ngigi, is a good example. Governor Rotimi Amaechi of Rivers State did not contest the April 2007 General Election but the Supreme Court declared him the winner of an election he did not contest because the elites were solidly behind him. Otunba Omisore won a senatorial seat while in detention. The list is endless. All these are the handwork of elitism.

Another dangerous aspect of elitism as practiced in Nigeria is the sit-tight syndrome and the burning desire to hold tenaciously to power. Once a Nigerian has got into the elite class, it becomes very difficult to descend. All the big names 
in Nigerian history are still part of the ruling elite till date. Gen. Olusegun Obasanjo (Rtd.), for instance, was a career soldier before serving twice Nigeria's Head of State. First, as a Military Head of State between February 13, 1976 to October 1, 1979 and second, as a democratically elected President from May 29, 1999 to May 29, 2007. He still dictates the tune of Nigerian politics till date. Similarly, Gen. Mohammadu Buhari (Rtd.), who was Governor of North-Eastern State of Nigeria from August 1975 to March 1976, Federal Commissioner (Minister) for Petroleum and Natural Resources from March 1976 to June 1978 and Head of State from December 31, 1983 to August 27, 1985, is still clamouring to return to Aso Rock as President of Nigeria. He contested the April 2003 Presidential election under the platform of ANPP (All Nigerian People's Party) but was defeated by President Olusegun Obasanjo of the PDP by a margin of more than eleven million votes. Again, he contested the April, 2007 Presidential Election still under the platform of ANPP but was also defeated by the Late President Umar Musa Yar'Adua. In March 2010, Buhari left the ANPPfor the CPC (Congress for Progressive Change) and was the CPC Presidential Candidate in the April 16, 2011 General Election, polling 12,214,853 of the total votes cast. He was again won by Dr. Goodluck Ebele Jonathan of the PDP who polled 22,495,187 of the total votes cast. Buhari rejected the results and vowed openly to make the country ungovernable for Dr. Goodluck Jonathan. He is still eager to contest in the 2015 General Elections if given the ticket by his new party, APC. This politics of desperation, bitterness and rancor among the elite class has not and will never lead to democratic consolidation in Nigeria.

\section{Roles of Political Parties in the Consolidation of Democracy in Nigeria}

In advanced democracies, political parties form the pivot on which the wheels of democracy rotate. In peripheral democratic states, especially those with long years of military dictatorship the Nigeria, the relevance of democracy lies in the conduct of manipulated elections, sharing of national loot and manipulation of the constitution under the pretext of constitutional review to accommodate the whims and caprices of political office holders. Here, the roles expected of political parties are limited to the fielding of candidates for various elections and canvassing for votes from the electorate. But Nwafor-Orizu (2011) has argued that the simple case of conducting an election into various public offices under different political umbrella does not alone reflect democracy in action. Any democracy that does not go beyond the conduct of election is half-baked democracy. Ironically, Nigerians are prepared to accept this half-baked democracy because half bread, according to them, is better than none. Again, the worst elected civilian regime is better than the best military dictatorship. This line of thinking is faulty. If we accept half bread (half-baked democracy), what happens to the whole bread (full democracy)? Nigeria needs full-blown democracy and this can only be possible if the political parties in the country are alive to their responsibilities.

Political parties are therefore expected to develop and work with articulate political ideologies, to screen and select candidates for elective positions, to formulate coherent public policies, the provision of political education on regular basis for the masses, serving as intermediaries between the government and the people and checking the excesses of the government in power (ruling party) with constructive criticisms devoid of bitterness and rancour.

It is obvious therefore that the survival of the democratic processes is directly linked to the ability of the political party (parties) to exhibit the above roles in a manner that will lead to the stabilization of the democratic regime. Drawing from his experience in Mali, Richard (1993), argues that the degree to which a party system is able to meaningfully contribute to the political process is related to the existence of several factors including the development and maintenance of strong party organization and the degree of the institutionalization of the party.

From the above, it is obvious that the existence of vibrant political parties seem indispensable for the consolidation or sustenance of democracy in any polity. In Nigeria's first and second republics, political parties were regionally based and their activities led to the collapse of those democratic experiments. From then till date, Nigeria is always guilty of lacking a sustainable political party system based on a coherent ideology. Political parties in Nigeria are usually formed along ethno-cultural, geo-political and religious lines as observed by Ball (1983). This has not helped the consolidation process since it encourages ethnic chauvinism and parochialism, irredentist sentiments and geo-political exclusiveness.

\section{Political Parties and Electoral Process in Nigeria}

Elections are the instruments through which the government derives the consent and mandate of the governed. But the shortcomings in the formation and organization of political parties in Nigeria, like contagious diseases, have contaminated the entire electoral process in the country. Every election conducted in Nigeria is usually accompanied by threatening controversy ranging from rejection of election results to filing of court cases against declared winners of elections. In the 2003 Presidential Election, Gen. Mohammadu Buhari of ANPP was defeated by President Olusegun Obasanjo of PDP by 
a margin of more than $11,000,000$ (eleven million) votes, yet he refused to accept the results. In the just concluded Governorship Election in Anambra State held on November 16, 2013, Chief Willie Obiano of APGA polled a total of 180,178 votes as against 97,799 votes polled by PDP, 95,963 votes polled by APC and 37,495 votes polled by the Labour Party (LP) (Vanguard, December 1st 2013). Yet the defeated candidates saw no transparency in the organization and conduct of the election by INEC and have therefore vowed never to accept the results. This, by implication, means that election results in Nigeria are not trusted and that votes do not actually count in the country. Hence, the electoral process in the country does not truly serve as a peaceful and transparent means of a change of government. Nigerians are made to believe that any candidate in the good book of the ruling elite wins elections with or without the electorate's votes.

The Nigerian electoral process therefore, reflects a Hobbesian state of affairs where each party is always at war with the other party and is ready to employ any means to achieve political power. Such a tendency only creates obstacles to the smooth functioning of the democratic process and bears witness to the fact that political parties in Nigeria have failed to live up to expectation. The Nigerian political climate is thus characterized by political intolerance and lack of intra and inter-party democracy. Politicians and party leaders have abused democracy and the democratization process in Nigeria to the extent that they have taken party politics to mean insatiable thirst for power, wealth and influence for personal and parochial ends rather than as means of consolidating political and economic development, for promoting societal welfare, for laying the foundation for national security and for socio-economic and technological transformation. For these reasons, our political parties - PDP, APC, APGA, LP, ANPP, etc. have not truly served as agents of democratic consolidation in Nigeria.

\section{How to Consolidate Democracy in Nigeria Via Political Parties}

For democracy to be consolidated in Nigeria, the following recommendations should be given first class attention.

$>$ Encouragement of political competition and political participation: Healthy political competition and mass participation in the political process are clear signals of democratic growth. Inter and intra-party squabbles should be discouraged while a conducive atmosphere should be created for mass participation in political activities.

$>$ A total overhaul of the present electoral laws regulating party registration should commence without delay. To achieve this, the independence of critical political structures and state agencies such as the Independent National Electoral Commission (INEC), the Economic and Financial Crimes Commission (EFCC) etc/ should be strengthened to enable them discharge their constitutional duties without interference.

> Nigerian political parties should be built on solid ideology and sound political philosophy that will enable them actualize what are stated in their manifestoes. Registering political parties without sound ideologies is like registering candidates who have not gone to school for public examinations.

$>$ The linkage between political parties and ethnicity or religion should be discouraged. The spirit of nationalism and patriotic sentiments should direct the formation and organization of political parties in Nigeria.

$>$ Nigerian opposition parties should play clean politics: all registered political parties in a multi-party state like Nigeria cannot at the same time be the ruling party. The party voted in by the electorate should be treated with respect and given the chance to execute its policies and programmes. Opposition parties should serve as watch-dogs of the excesses of the party in power instead of pursuing politics of desperation, bitterness and rancour.

\section{Conclusion}

There is no best form of government anywhere in the world. The best form of government is one that is best administered. Nigeria's democratic experiment will yield positive results if the ruling party as well as the opposition parties were ready to employ decency and decorum in the way and manner they administer the polity.

The obstacles in the democratization process in Nigeria lies not in the form or type of government but in the style our leaders adopt in governing the masses. Democracy has not been fully or even partially consolidated in Nigeria because the political parties in operation since 1999 till date are not ready to sustain the ideals of democracy. Democracy can only be consolidated in Nigeria if the above recommendations are given priority by the government of the day and if the existing political parties imbibe the tenets of democracy and stop the politics of desperation. 


\section{References}

Achebe, C. (1980). Trouble with Nigeria, Enugu, Fourth Dimension Publishers.

Adebayo, A. (1986). Power in Politics, Ibadan; Spectrum Books Ltd.

Ball, A. R. (1986). Modern Political Parties, London Macmillan.

Chaturvedi, A. K. (2006). Dictionary of Political Science, New Delhi: Academic Publishers.

Akandi, Bisi (Former Governor), "How to make Nigeria a true Nation." The Guardian, Wednesday, September 12, 2007 p. 9.

Deegan, S. (2003). Democratic Institutional Reforms and Political Conflict: Evaluating Alternative Explanations of Electoral Reforms: Costa Rica, Hellen Kallogg Congressional Review Services.

Emiri, Festus (2010). Dealing with Electoral Fraud: "The People, Security Agencies and the Law", A Paper presented at the 1st PCRC Conference in Port Harcourt on 25 $5^{\text {th }}$ October, 2010.

Sarabjit, K. (2002). "Challenges of Democratic Sustenance in Nigeria", A Paper presented at the Centre for Democracy and Development, Lagos, July 5, 2002. 